\title{
Transvestite Logic: Pat Mills and Kevin O'Neill's Marshal Law and the Superhero Genre
}

\author{
Kiernan Cashell and John Scaggs
}

So go gently with our fantasies, Marshal Law. We have to believe in the myth of the superhero. Reality is too much to bear. - Commissioner McGland

Following the official announcement of the death of Christopher Reeve on October 102004 , popular news networks, international reports, broadsides and tabloids of every color broadcast faux-naif proclamations announcing the demise of Superman. Newspapers produced a maelstrom of headline permutations of tasteless clichés like "SUPERMAN'S LAST STAND." There was nothing surprising or unbecoming about this typecast misidentification. Since the 1978 blockbuster movie Superman in which he played the eponymous role, Christopher Reeve and the superhero had fused into a single entity in popular imagination. In a perverse kind of Messianic incarnation, the theological mythos of omnipotence had been effectively reified by director Richard Donner into the God-man hybrid through the illusionist verité of advanced cinematography (and some inspired casting). And collective cultural consciousness proved all-too-willing to accept this absurd compromise of the second coming.

Two events exposed the fundamental vulnerability at the heart of the mythology of "the man of steel." First, the fictional Superman (i.e., the original comicbook superhero) met his death at the hands of Doomsday in the 1992 series The Death of Superman. ${ }^{1}$ Second, three years later, like something directly out of a Greek tragedy, the flying omnipotent was again grounded in the cruellest fashion. In 1995 a vertebral trauma sustained as a result of a riding accident in Virginia left Christopher Reeve in a state of general paralysis. Confinement to a wheelchair seemed a pitiless

Kieran Cashell is a lecturer at the Limerick Institute of Technology, Ireland. John Scaggs teaches in the English Department at the Mary Immaculate College of the UNiversity of Limerick. 
but classical punishment for hubris. For fans therefore the period of mourning had already undergone its stages of Durcharbeit by the time America's favourite superhero really died; the Manichean struggle between good and evil had already long been decided. For those who more soberly monitored Christopher Reeve's indefatigable campaign for medical research into radical treatments for spinal injury, wondering if this would result in recovery, defeat had also to be admitted. For all of us, it was the epoch of the superhero that passed away quietly in the night.

This paper is an autopsy. Using a forensic methodology, we intend to investigate the superhero genre in its present cadaverous state. Firstly, therefore, we should admit without hesitation that we consider Mills and O'Neill's Marshal Law to have already carried out this forensic investigation. In particular, the series Fear and Loathing reveals the moribund state of the superhero genre through an uncompromisingly satirical exposure of what is represented in the series as the decadent period of superhero history. Therefore, as it contains most if not all of the material for this investigation, our analysis will be restricted for the most part to Marshal Law: Fear and Loathing $(1988-89,2002) .{ }^{3}$ Despite its prior claim to this type of investigative revision of the genre, Marshal Law has received remarkably little critical attention in the theoretical literature. Perhaps this is due to its implacably negative attitude towards the genre, which (especially in the later series) approaches the nihilistic. To take Mills and O'Neill's project seriously would be to concede that this transgressive text represents an important critical commentary on the genre. Or perhaps it was tempting for readers to dismiss it along nationalistic lines as a British intervention into an originally and traditionally but far from exclusively American genre; and indeed, for the creators of Marshal Law a critique of the superhero necessarily involves a political critique of American society. ${ }^{2}$ These suggestions may explain why Mills and O'Neill's intervention did not have a significant impact on the genre. Even the most important critical revisions of the $1980 \mathrm{~s}$ were for the most part respectful of the tradition; and, because die-hard fans of the genre will generally not be well-disposed to such vicious revisions as Marshal Law, the comic probably appealed more to a typically non-comic-reading audience. Admittedly therefore Marshal Law had little or no impact (either of a commercial or of an influential-creative nature) on the superhero genre; its insult was parried and absorbed by a very resilient and porous genre: its effects remain historical and now, regrettably, purely rhetorical.

Conceived by writer Pat Mills and artist Kevin O'Neill, Marshal Law was first published by Epic (an imprint of Marvel) as a bi-monthly in 1988-1989. The story is set in the city of San Futuro (a metropolis built on the remains of a San Francisco now levelled by earthquake). During a protracted war with South America, a Government-administered biotechnology programme was established to engineer humans with "superpowers." Many of these genetically modified superhumans were processed specially for combat in the South American "Zone." Now that the war has ended in deadlock, these super-soldiers have returned as veterans, traumatised by high-tech warfare. Hungry to express their appetite for destruction, they have formed provisional paramilitary mobs and are terrorising the streets of San Futuro. One of those who fought in the Zone, Joe Gilmore, has returned to the city disillu- 
sioned with the idealism and propaganda that influenced him to volunteer. He now targets all his biotechnologically-induced aggression into one project: to hunt down and purge the city of depraved superheroes. He joins the San Futuro Police and becomes Marshal Law, a hard-boiled Mad-Maxian cop with the capacity to deal with the superhero situation. However, there is one superhero in particular that Law believes should be brought to account for his role in encouraging so many naive youths to travel to the Zone: the Public Spirit. He is convinced that under the stainless American-dream profile of the Public Spirit lurks just another caped degenerate. Marshal Law is going to expose him for what he really is. Mills, who previously worked in collaboration with O'Neill for influential British weekly 2000AD (most notably on the excellent Nemesis the Warlock), ${ }^{4}$ discusses the provenance of the Public Spirit in an introduction to the 2002 edition of Fear and Loathing, saying, "he's based on an image - an image of the hero that is utterly artificial. He's got a bit of ex-President Reagan in him; Reagan as a young man was a hero, an athlete, a figure of virility," he adds: "He's also got a bit of Barry Manilow too" (Mills \& O'Neill 2002). But, basically, the Public Spirit is designed to represent the genre: he is meant to be the prototypical superhero.

\section{Marshal Law in the Superhero Genre}

This analysis will begin by contrasting Mills and O'Neill's intervention into the realm of the superhero with the other principal revisionist tendencies within the genre. Marshal Law can be distinguished from such critical re-evaluations of the superhero genre as Alan Moore's Marvelman (1983, with Gary Leach and Alan Davis) and Watchmen (1986, with Dave Gibbons), or from critical rehabilitations of the genre like Frank Miller's acclaimed The Dark Knight Returns (1986), Moore's The Killing Joke (1988, with Brian Bolland) or indeed, Grant Morrison and Dave Mc Kean's Arkham Asylum (1989). Mills and O'Neill are not so genuinely concerned with the superhero genre as to desire to question its fantastical (or psychologically suspect) bases by developing new textual strategies influenced by cinematic devices (thereby fortifying the genre at a higher level). Nor are the authors of Marshal Law particularly interested in rehabilitating a genre reaching exhaustion by providing complex and emotionally involving narratives for a mature and knowledgeable audience that requires its fictional interactions to have a contextual (i.e., socio-psychological and historically genre-referential) sophistication. In opposition to these re-evaluation and rehabilitation strategies, Mills and O'Neill seem more intent on precipitating the termination of what is obviously (to them, at least) an incapacitated framework. The political agenda played out in the storyline of Fear and Loathing therefore effects a rhetorical agenda: anti-superhero Marshal Law's objective to forcibly reveal the private reality behind the fraudulent Public Spirit initiates an investigative exposure of the entire genre.

Because it subverts, interrogates and transgresses every salient characteristic associated with the genre, it certainly seems appropriate to consider Marshal Law: Fear and Loathing a "deconstructive comic" in Schmitt's sense (Schmitt 1992). Indeed, because "it mocks and mirrors Marvel's own products [and] almost every 
major hero and convention is taken to task," according to McCue and Bloom, the text can be classified as a deconstructive "metacomic" (McCue \& Bloom 1993, 64). However, we believe that there is something more going on here than deconstruction. Like an undercover mole, Marshal Law examines the conventions of the superhero code by infiltration, ceding to those conventions only in order to critically investigate them more thoroughly, more intensively. Thus, on one level (and admittedly a very superficial level) Marshal Law appears to correspond exactly to a regular superhero comic. Yet this appearance is accompanied by the aware-

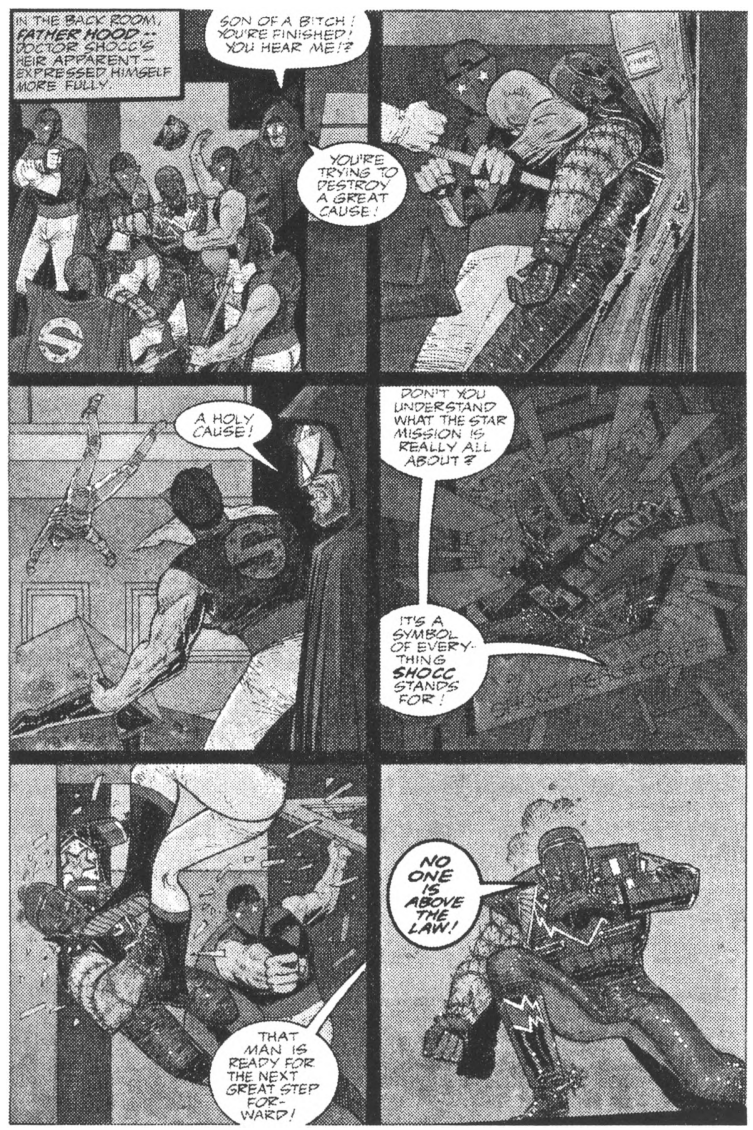
ness that the text is a complete aberration - an obscene pastiche - of the genre. As opposed to Moore's reevaluation strategies therefore, Mills and O'Neill do not attempt to construct cunningly plausible alibis to account for the presuppositions that the plot of Fear and Loathing is narrated around. Rather they parasitically appropriate what Mills himself described as the "undemanding, vacuous" framework of the superhero genre for the purposes of satirically undermining that very framework (Mills \& O'Neill 2002). Despite this however Fear and Loathing is an incredibly rich text.

Although Marshal Law is the protagonist of the narrative and the reader is notso-gently inveigled to align to his perspective, a heteroclite diversity of narrative foci proliferates in the text. For instance, the linear narrative is impelled forward through several heterogeneous phenomenological first-person viewpoints. These fragmentary perspectives gradually converge at the climactic peripateia of the story. And the authors have used various indicators to mark the moment when a different narrative perspective has been ushered into the text to occupy the void of the personal pronoun. Tone of voice or accent of individual speech-act is the most subtle of these devices, and color-coding and shape of text panels, the most obvious. For instance, whenever it is intended that we read the narrated sequence of 
events from the perspective of the Sleepman, the field-color of the text-panels changes to a sickly grey and their bottom edge morphs horribly into an ooze of dribbling matter. On the other hand, at a certain point in the narrative, when the reader is intended to vicariously occupy Celeste's perspective, this point-of-view change is marked by the innocent pink color-field in the dialogue boxes.

This is an elementary story-telling codification device and there is nothing really remarkable about it. The central variance in this case however is that, as well as an indication of alternative presences in the text, it also indicates the presence of structural heterogeneity as such (which, as Mills indicates, was the initial motivating aim of the project). This "polyphonic" mode of presentation whereby "polyvalence" is infiltrated into the text and "codified discourse" is thereby "exceeded," is wholly appropriate to the "carnivalesque" world represented in Fear and Loathing (Kristeva 1980,71, 65). In the concluding sections of this paper we will argue that the theory of the carnivalesque has considerable explanatory potential for the thematisation of a polyvalent text like Marshal Law; for the concept of the carnivalesque enables us to theorise Mills and O'Neill's approach to the superhero genre on three distinct levels. First, and most importantly for our analysis, it characterises the type of critique accomplished by the text which, we will conclude, even though seeking to subvert the salient laws of the genre, cannot do so effectively without at the same time adapting to those laws. Second, the category explains why the world depicted in Marshal Law appears the way it does; as Umberto Eco argues in a pioneering analysis of the superhero, the "iterative scheme" identified with the generic framework, actually "sustains and expresses a world;" this world, Eco concludes, shares the same "configuration" as the scheme through which it is represented (Eco 1979, 122). Third, the category of the carnivalesque (not necessarily employed here as an affirmative-valued category) represents the truth of the superhero genre as exposed by Mills and O'Neill in Marshal Law. Before we can argue for this claim properly however, it is necessary to characterise the demands that a polyvalent text imposes on the reader and the strategies of reading made possible by it.

As stated, there is a continuous vacillation in Fear and Loathing between different narrative modalities: the narrative shifts and shimmies in and out of the dominant linear story. One of these threads is actually used to develop a critical commentary on the unfolding story. This commentary intrusion is introduced diegetically into the text in the form of a series of typewritten quotations from Lynn's thesis on the superhero. (Lynn is Joe Gilmore's lover who remains unaware of his secret identity as Marshal Law). The implication is that Joe has read Lynn's critique of the superhero and that certain propositions from that work have begun to haunt him in his capacity as Marshal Law. Furthermore, these quotations constitute fragments of the critical theoretical approach to the superhero genre that underpins Mills and O'Neill's project. Lynn writes: “As optimism about the future gives way to pessimism, so hero is replaced by anti-hero. Of them all the most brutal is 'Marshal Law." Thus Marshal Law is theorised as a kind of super-antihero. We can imagine Mills and O'Neill developing this nascent idea into a visual image: "With razor slashes down each cheek, looking as if his throat's been cut ..." 
(Mills \& O’Neill 2002).

In that it contains its own theoretical commentary as an immanent part of its discursive structure therefore, Mills and O'Neill's text demands a reading state (strangely appropriate to a genre characterised by double identities and split personalities) that approaches the schizoid. And this is because a second phase of critical reading is introduced into the structure of Fear and Loathing (through Lynn's thesis) that involves (in the words of Simon Critchley) the "destabilisation of the stability of the dominant interpretation" (Critchley 1992, 26-27). The effect of this reflexive theoretical meta-text interwoven thus diegetically into the narrative is to undermine the genre that it depends upon for its own representation. This technique means that assimilation to the codes of the genre involves a rejection of those codes; thus the preferred reading of the text is actually experienced by the reader of Fear and Loathing as an oppositional reading.

The levels of reading that effectuate this destabilisation in Fear and Loathing are compounded and multiplied by Kevin O'Neill's contribution to the text. O'Neill does not simply illustrate the narrative but rather (to draw on Cobley's distinction between story and narrative) interprets the story ("all the events to be depicted") through an alternative modality (Cobley 2001, 5-6). Cobley defines narrative as the "mode selected" for the "showing and telling" of the events of the story (Cobley 2001, 6). Each narrative mode in Fear and Loathing selects different aspects of the same "story" or fabula for depiction. Unlike artists who are content to supply the visual component of the story according to the writer's principle direction, O'Neill's idiosyncratic drawing style means that it is impossible to conceive of the iconic component of the text as auxiliary.

Through his dense and angular artwork, O'Neill contributes his own narrative representation of the events of the story. This is exemplified by the diegetic textual elements scattered through his panels in the form of graffiti or advertising quotations, posters, T-shirt slogans and tattoos. This slows the reader down, prevents scanning of the artwork and introduces another fragmentary, elliptically iconic (and indeed, non-linear) mode of reading into the text. O'Neill's creative and "producerly" contribution to Fear and Loathing (where, it seems - disturbingly - that he has been given complete artistic freedom) therefore means that the artwork can never succumb to the codified transparency Barthes has characterised as the "déjà-lu" (Barthes 1988, 191): in that he appears to constantly avoid the injunction to reconstruct the text's "dominant interpretation" (and not just in his work for Marshal Law) O'Neill's imagery contributes to the schizoid levels of reading in Fear and Loathing because it also involves a destabilisation of the dominant meaning of the text.

\section{Conduct Unbecoming: The Public Spirit}

Issue four of Fear and Loathing features a full-page inside cover image of the Public Spirit, the official all-American superhero, pride of the establishment, universal role-model of the youth, housewife fantasy-man. Sitting on the toilet, a ligature around his extended forearm and clamped tight between his teeth, the Public Spirit, 


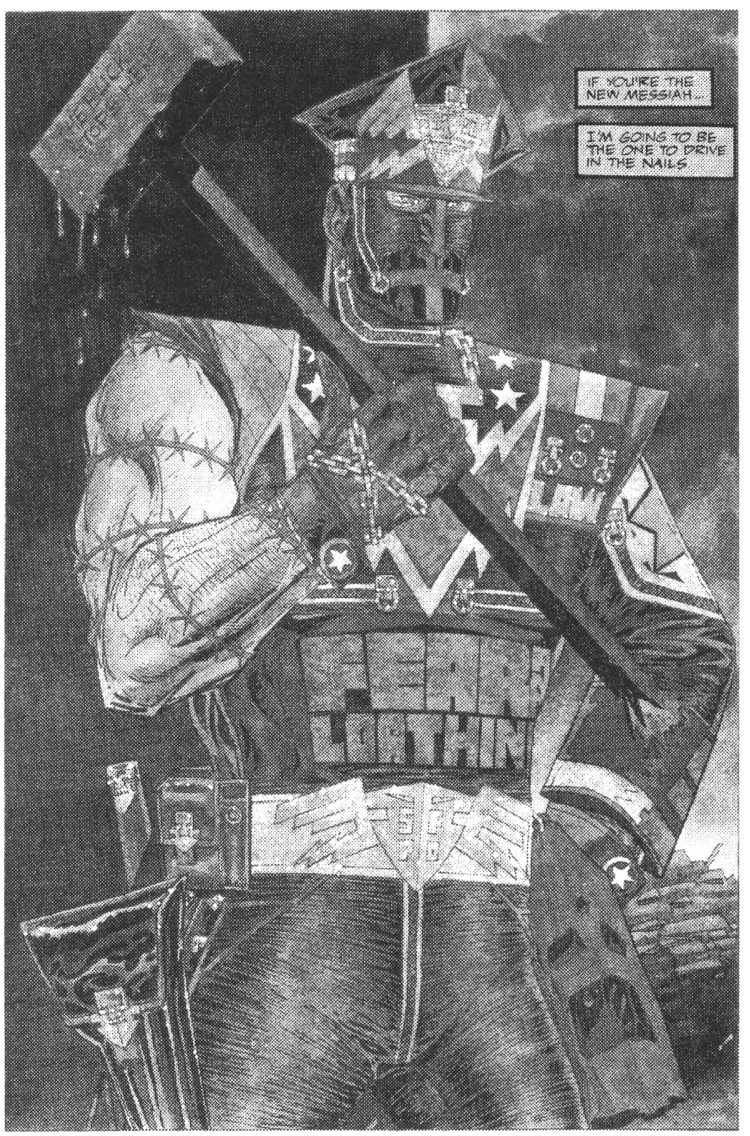

in his brightly colored costume, applies a syringe to one of the knotted veins in his arm. Bottles, phials and assorted pills are strewn around his tiny feet. The superhero is shooting up.

This unforgettable, unforgivable, paradigmatic image, more than any other, remains a synecdoche, representative of the general approach to the destabilisation of the superhero genre undertaken by the creators of Marshal Law. In this sense, the image functions monadologically as the over-determined plexus through which the entire meaning of the work flows, is concentrated and revealed. Like the monad, the image functions like a convex mirror that reflects the textual universe of

Marshal Law in its surface. In interview, Mills attributed the provenance of this iconic image to the artist Simon Bisley who remembers: "I did a pisstake picture of a little superman with a needle in his arm and Pat was interested in it" (quoted in Bonner 22). Bisley continues: "It's the thing about all these superheroes going around saving the world - and they're all on steroids ..." (22). From this modest "pisstake," Mills suggests, the concept of the Public Spirit developed For his characterisation, Mills and O'Neill have obviously plagiarised Superman ("standing for truth, justice and the American way"), the prototypical superhero (who remains the paradigm case) ${ }^{5}$ But the Public Spirit also incorporates traits associated with Captain America (in particular his paranoid patriotism as reflected in his star-and-stripe costume of ultramarine, white and scarlet emblazoned with Golden Eagle motifs). ${ }^{6}$ Captain America was a product of Second World War xenophobic "fantasies of superhuman power" triumphing over "devastatingly dehumanising" alien forces of subversion (quoted in Trushell 2004, 151). Such paranoiac-patriotic heroes (Bucky, the Eagle, V-Man, The Shield, The Star-Spangled Kid, Stripsey and Uncle Sam as well as Captain America) only made explicit an ultra-conservative American nationalism intrinsic to the superhero concept since Superman (McCue 
and Bloom 26-27). The Public Spirit's exclusionist xenophobic (and homophobic) patriotism is expressed very clearly throughout Fear and Loathing (especially at the end where he is "stressed"): "That's what's wrong with this country today ... the feminists and the pinkos and the faggots are trying to take over ... spreading subversion like AIDS!' (Mills \& O’Neill 2000). However, unlike Captain America (but like Superman), the Public Spirit wears a "cape" signifying his flying endowment (only certain superheroes are empowered with the capacity to fly). In general, therefore, it is possible to suggest that Mills and O'Neill's superhero is conceived (for the purposes of subverting the code) as an amalgamation of the identifiable codes and familiar characteristics of the conventional superhero mythos condensed into one clichéd (and bloated) super-ego.

According to Freudian psychoanalysis, the super-ego is a psychological agency that represents an idealised and amplified (sub)version of parental (moral) power. Blown up out of all proportion, this "higher moral nature" is lit-

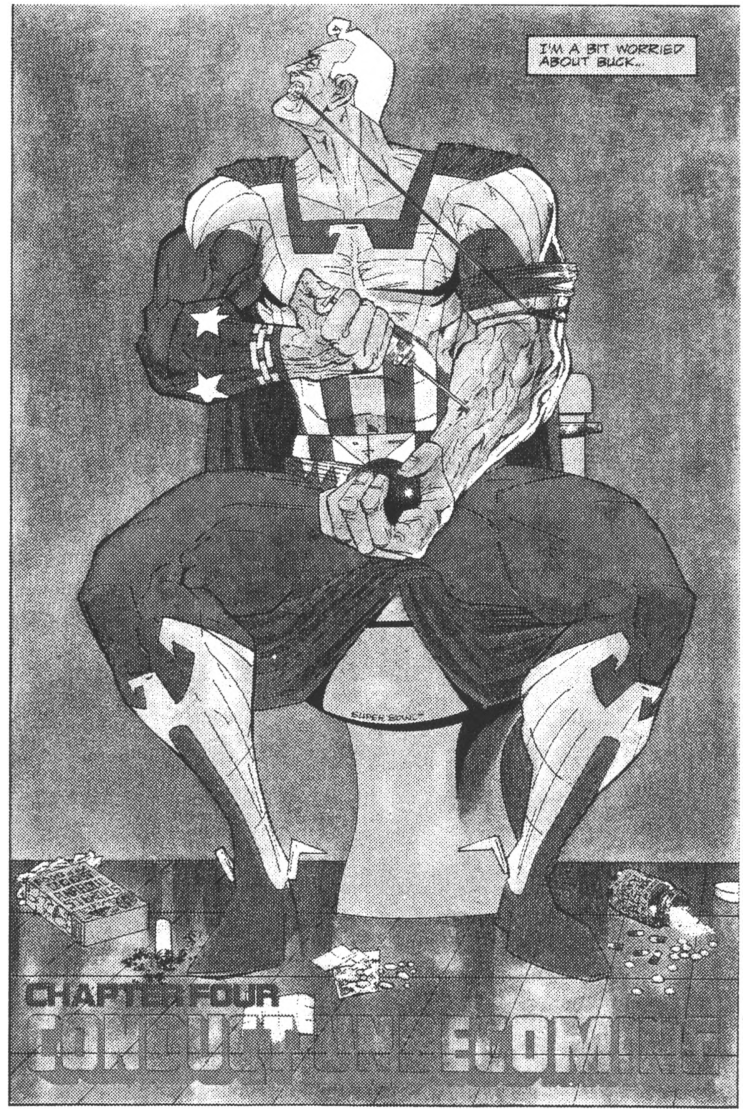
erally a super-power. In a passage that sounds exactly like something from a generic superhero story, Freud announces:

When we were ... children we knew these higher natures, we admired them and feared them; and later we took them into ourselves. (Freud 1995, 643)

And of course, the moral-parental status of the superhero reinforces this conception of the superhero as superego-ideal: superhuman power is employed only to do Good, to achieve Justice beyond the laws of fallible men, to fight evil and corruption in all its fantastic forms. 
Resisting the temptation to employ the techniques of psychoanalysis to unmask the superhero, Eco points out that the template of the superhero is universal, systemic and venerable: its lineaments can be discerned in the mythical hero of native legend. In Samson and Theseus, for instance, the seeds of the superhero's omnipotent but ethical, supreme yet benevolent, transcendent yet humanist values were sown (107). For in such exponential hero-values there is something that, although far in excess of weak, corruptible individuals, can be aspired to (as our limited capacity is simultaneously acknowledged). As many commentators have since indicated, it is the placement of the superhero within the realm of the contingent and everyday that gives the genre its particular imaginative power. For instance, Reynolds observes that the "extraordinary nature of the superhero will [constantly] be contrasted with the ordinariness of his surroundings" (16). And Eco, already arguing in this vein (as we have seen), contends that the superhero is continually "accepted" only because the aspects of eternal myth that he enjoys are situated in "our human and everyday world of time" (111). In fact, according to this schema, the superhero can be conceived as a unification of two archetypal heroes: on the one hand, the superhero is heroic because s/he takes on immense forces and triumphs over them in a truly sublime-tremendous capacity; however, on the other hand, the superhero is simultaneously (that is in the same person) "one of us," an ordinary everyman or woman who has to struggle to deal with the mundane problems and manifold little injustices of a humdrum workaday reality. Thus, according to Reynolds, "the extraordinary nature of the hero will [constantly] be contrasted with the mundane nature of his alter-ego" (16). It is the protagonist's double existence that ensures both types of hero are given equal portrayal in the superhero genre. But it is through the alter-ego function that the fantastic figure of the superhero is able to side with and support the ordinary, unremarkable, tax-paying citizen. Therefore it is clear, according to Reynolds, that nearly everything "that would become central to the superhero genre" was "established in [the] thirteen pages" of the first Superman issue $(1992,12)$. When he becomes aware of his special prowess, Clark Kent makes a vow "to dedicate his strength to the service of mankind, and becomes Superman - 'Champion of the oppressed,' this physical marvel who has sworn to devote his existence to helping those in need."

In issue six of Fear and Loathing, a series of bubble-gum cards depict the Public Spirit involved in typically superheroic altruistic missions. Beneath each stylised image runs a legend: "Conquering the Stars," "No More Slums;" "Rescuing a Nun;" "Rescuing a Dog;" "Rescuing an Orphan;" and the final card, which shows the Spirit in mid-flight, saluting, with the skies organised into a simulacrum of the American flag, reads: “A Job Well Done” (Mills and O'Neill 2000). These images, taken together, constitute an elliptic representation of the clichéd mythos of the superhero. A quotation from Lynn's thesis is used to comment on the official myth as promulgated in these cards:

The Public Spirit cards, painted in bright optimistic primary colors, make his feats seem easy and attractive to children. There is no attempt at realism. (Mills and O'Neill 2002) 
However, Marshal Law believes the truth is otherwise and has been systematically concealed by such ideological smokescreens. His mission becomes the effort to expose that truth: to demystify the official myth of the superhero. And that is the project he has devoted his existence to. The quasi-syllogism that the eponymous protagonist repeats throughout the series effectively summarises this central thematic concern of Marshal Law: "I'm a hero hunter ... I hunt heroes ... haven't found any yet."

On his return from his expedition to "the stars," the Public Spirit chairs a press conference to address his devoted audience. Marshal Law attends. He quizzes him about an incident that occurred prior to his expedition in which the Spirit's first fiancée, Virago (another superhero[ine], a "Siren") was killed. According to official reports, she drowned during a storm.

"You were with her at the time?" Law asks. "She fell into the sea during a storm. I failed to reach her in time." Marshal Law is incredulous: "Our greatest superhero couldn't carry out a simple sea rescue?" Law suspects that the Spirit murdered Virago because of his careerist ambitions; conscious that Virago would have aged twenty-five years during his sojourn in the cosmos and that this would have made their marriage problematic, the Spirit beat her to death out in the open sea. However, her body was never found.

"But," The Spirit protests, "I loved Virago. If I'd wanted to go on that mission so badly, I could simply have broken off our engagement ... and still have been selected."

"Not if she was carrying your child!" Law retorts.

"You may have loved her, but you loved success even more! You had to satisfy your own ruthless ambition! Your desire to get to the top! To the stars! No matter what the cost! Even if it was murder!" (Mills and O’Neill 2002)

Things become ugly: the conference descends into chaos. Cameramen are threatened. And as Marshal Law is dragged away by three costumed bouncers, he shouts out a series of rhetorical questions:

"Was there a cover-up? Was it all hushed-up, huh? Did it leave you feeling like shit? Killing your own child? Did it frag up your head?" (Mills and O'Neill 2002)

This aspect of the narrative brings into focus another "basic motif" of the genre: "the departure from one condition, usually psychological immaturity or physical dependency, in order to achieve individual and communal success" (Bongco 102). In Marshal Law, the Public Spirit and Virago were among the first successful results of Dr Shocc's genetic engineering research into the simulated acceleration of evolutionary sequences through technologically selected mutations:

Using computer simulations to associate the random forces that 
create evolutionary leaps and mutations, [Dr Shocc] began designing the men and women of a million years in the future. (Mills and O'Neill 2002)

As they grew up, the two "experiments" formed a profound alliance; their union was pre-determined, co-dependent and inseparable. Absence of parental guidance in the life of the superhero from a relatively young age is a common convention associated with the superhero genre. Fingeroth argues that (what he terms) "the orphan condition" associated paradigmatically with the genre is key to the pattern of reader-identification peculiar to the superhero (78). Yet again a Freudian explanation suggests itself here. Identification with a fictional character whose proper parental guidance has been obliterated from his/her life allows an imaginative transfer of identification from the real parent(s) to a superhero who seems a more appropriate personification of the sublime authority associated with the super-ego. According to such a displaced pattern of identification, the superhero comes to represent a form of totemic moral protection against harmful and corruptive influences; and, like the agency of the super-ego, the hero is concealed within the deceptive casing of a seemingly ordinary existence.

However, Fingeroth suggests another interpretation of the orphan criterion that, as we will see, is more congenial to our present purposes. He argues that the vicarious satisfaction associated with the orphan premise is related to the myth of the tabula rasa: for the removal of loved protectors (or, conversely, the removal of those who could have been protected by the kind of powerful being the hero will later become) liberates the orphan into a premature yet remote autonomy. And the traumatic originary event that leaves the orphan alone can henceforth be interpreted as an initiating sign pointing toward the hero's vocation. This provides an alibi for the character's development of novel or strange alternative personas later in life. The orphan state therefore gives the superhero a kind of moral licence for his/her subsequent actions; it also, significantly, provides a fictional basis for the cold ruthlessness of the person who knows they have nothing left to lose anymore.?

Now this process of transcendence through loss of dependency (usually involuntary in the case of the superhero's loss of parental security) necessary to the genre is closely related to Nietzsche's notorious conception of the Übermensch ("super-man"). Yet, in the case of the Public Spirit, he himself precipitates his emancipation from Virago through eliminating her from his life by his own hand. And the incompatibility of the Übermensch and superhero is brought into high relief here. For, ironically, the very moment when the Public Spirit demonstrates his echt-übermenchlich capacity to transcend the socio-symbolic moral order (by getting rid of Virago), he thereby rescinds his super-heroic status. This is because his act of übermenchlich transcendence entails a transgression of the moral law - he committed murder (at least Law thinks so). And in this context, it must be realised that the supervillain also possesses superhuman powers - with the central and obvious difference that they typically (ab)use their powers for self-motivated interests or material gain. Thus, in the superhero genre, it is the villain who is properly übermenchlich in the Nietzschean sense. But as Reynolds points out, the 
supervillain is "corrupted" through using power for non-altruistic, self-interested motives (24). In an interesting combination of the two codes (undertaken again for critical intent), the Public Spirit becomes overt hero and covert villain in one character; he undermines the convention of the superhero with one murderous act. As well as the prohibition against employing power for self-interest, another precept associated with the code (that cannot be deviated from) is that the superhero must never exhibit a "lack of mental or physical control" (118). Marshal Law believes that both laws have been contravened. His hatred of the Public Spirit is therefore actually inspired by the Spirit's violation of the superhero code.

Although his advantageous position is not a choice the Spirit has made, it is, in another version of the lost parents criterion, an inheritance of his parents' voluntary subjection to Dr Shocc's experimental procedure on his behalf. His artificially induced powers are extraordinary: he has a "lethal physique," the power of flight, tremendous strength and powerful vision. But included in this catalogue of superhero characteristics there is one that is peculiar to Mills and O'Neill: an abnormally high libido. Superheroes (like the Spirit) cannot have sexual relations with ordinary people as their genetic advancement renders it dangerous and potentially lethal. Marshal Law therefore also suspects that the Public Spirit is responsible for the spate of mysterious rapes and murders of women that have recently been perpetrated in the city. All victims were dressed in the costume of Celeste, the Public Spirit's new fiancée. However, all that is known about the serial rapist-killer is that he conceals his real identity by assuming the persona of a kind of antithesis of the superhero: in his sinister costume, with long prosthetic metal claws, he calls himself the Sleepman and wears a bag over his head.

Most of the narrative is devoted to Marshal Law's attempt to build a case against the Public Spirit for the murder of Virago (and these related crimes). As mentioned, Law is driven by his hatred of the Spirit for encouraging people to fight in the Zone and thereby indirectly causing the deaths of hundreds of soldiers who had their bodies transformed by Dr Shocc's radical experimental treatments to make them into more efficient, fearless killing machines. It turns out that Marshal Law was himself one of the young men who volunteered to receive Dr Shocc's treatment in preparation for "defending" his country in the Zone conflict. And his pathological hatred of the Public Spirit is the result of classic ambivalence: his desire to emulate his super-ego role-model is inverted into the transverse desire to annihilate that ideal when he discerns the abject reality behind its mythological surface. The childlike awe becomes a very mature repulsion:

I had been inspired by the Public Spirit. ... He was always my special hero. ... He could take any amount of punishment and hand it out. But he'd always use his super powers for good. To help people. Never for evil. ... He was like the heroes in comic books. Forever young. I was five when I was first told about the dream, twenty-nine when I knew he and his kind had stolen it. (Mills and O'Neill 2000)

Many of the "heroes" who returned from the Zone became veteran "surps" (sur- 
plus heroes) with nowhere to vent their aggression and no combat situation in which to employ their ultra-efficient physiological proficiency. With no obvious enemy to kill, the streets of San Futuro are teeming with treacherous gangs of surplus-to-requirement, post-traumatic, psychotic superheroes (perfectly realised by O'Neill's depraved pen). Assuming ownership of certain areas of the metropolis, these gangs have inaugurated a reign of terror and transformed the city into an anarchic no-go dystopia.

"The new times called for new solutions. New ways of dealing with the lawbreakers." On his return from the Zone, Gilmore becomes an officer of a special branch of the San Futuro Police Department and dedicates himself to the use of his acquired powers to bring the out-of-control psychopathic superheroes to justice. Thus in Fear and Loathing, it is Marshal Law that comes to represent a form of justice that is transcendent in relation to the establishment bureaucracy that the legal institutional forms of justice assume.

Gilmore, in his Marshal Law (dis)guise, works not with the police department, but in it; he is a bona fide cop. However, it emerges very clearly in Fear and Loathing that his ingenuous perspective diverges dramatically from that of the institution he works for. When he presents his evidence against the Public Spirit to Commissioner McGland, McGland - "I'm a superhero myself: I'm a superliar" humours him by appealing, disingenuously, to his patriotism:

He makes his point (at considerable length) ... and I pretend I am interested. How do I answer his serious allegations about The Public Spirit? It's very simple. I lie. I tell him colonel Caine is under investigation ... but no action is being taken until after the wedding [to Celeste]. I explain about the scandal. And appeal to his patriotism. ... He always had that one big weakness - even in the zone. He still believes in the dream. That's why he hates the Public Spirit. Because he thinks he's betrayed the dream. (Mills and O'Neill 2002)

The corruption runs deep. Even at the end, Marshal Law never suspects McGland's directorial hand in the events that have played themselves out. McGland forces a public reconciliation between the Public Spirit and Marshal Law at a charity event where the Spirit hands over a large donation for indigent and post-institutionalised superheroes. This fiasco diverts public attention away from Marshal Law's impeachment of the Public Spirit and prevents a scandal that may lead eventually to disclosure and a very embarrassing trial.

Many principal elements of the superhero code coincide with the socio-symbolic construction of masculinity as such and its dual super-egoic ideals of control and power. In her thesis, Lynn argues that the myth of the superhero is founded entirely on the more fundamental myth of masculine virility. Having lost an article she needs for her thesis, Lynn asks for Joe's help. While searching their apartment, he asks what the article was about. "The secret symbolism of the Public Spirit. How he's really the ultimate phallic symbol of male power." She answers. "It's got all these quotes from the Public Spirit: how we can't go soft on the commies ... we 
have to stay firm ... with a cartoon of him holding an erect missile." When they finally find the article, thanks to O'Neill's realisation, we are shown an illustration with the Spirit sitting astride a missile with "Big Boy" (beside the American flag) inscribed on it. The heading reads: "The Pubic Spirit." During the search, Joe comes across an issue of Knee Deep in Shit (a "radical student zine") with a caricature of Marshal Law on the cover that reads "Marshal Law (less): Freedom Crushed while-u-wait." "Fascist Bastard" is inscribed on the huge gun he holds in his clawed hand and the words, "Nazi, Thug, Killer," run in small panels down the left side. "Yeah, I'm going to get him in [my thesis] as well," Lynn says. "Really? As a hero?" Joe asks. "As another prick," she replies. Later, she associates the masculinist myth of the (super)hero with homophobia: the "fear of homosexuality," she writes, "is personified in the macho hero, who is a denial of the duality of human nature" (Mills and O'Neill 2000):

Because the male concept of a hero is based on a false premise, false heroes - like the Public Spirit - are inevitable ... this falseness is becoming apparent in the aftermath of the Zone as the "heroes" come home and there are signs that he, too, could become a "surp," a "surplus hero." (Mills and O'Neill 2002)

The myth becomes insidious, she claims, when these false heroes are set up as role models and perceived as super-ego ideals by an impressionable youth culture. As personifications of the socio-symbolic construction of virility that constitutes the ideology of masculinity, these heroic super-ego-ideals become paradigmatic to "ordinary men who attempt to prove their virility by constantly achieving and succeeding in a society where failure is seen as a disgrace"

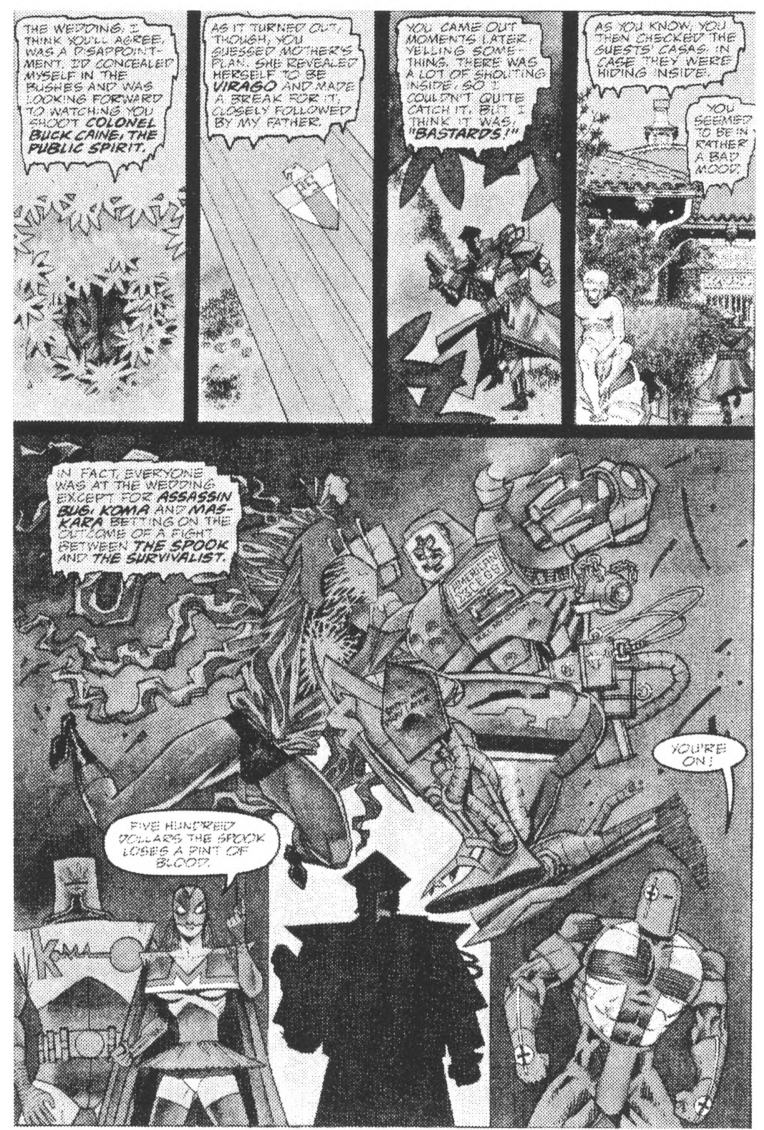


('female" weakness') (Mills and O'Neill 2002). Of course the implication is that unknown to each other, Lynn has worked out theoretically what her lover Joe (as Marshal Law) is more practically engaged with.

Like most superheroes, the Public Spirit and Marshal Law have dual identities: their public personas are styled largely in opposition to their private alteregos. Underneath Colonel Buck Caine's dark tailored outsize suit-jacket, he is the candy-colored Public Spirit, while underneath the black and red leather mask, the barbed wire, the gloves and chains, Marshal Law is Joe Gilmore: army-surplus exZone-militia man turned "hero-hunter." There is widespread agreement that the suspense generated by the consistent maintenance of a dual identity (and the psychological conflict associated with this - which in certain situations is pathologized into a split personality) is a fundamental narrative principle of the superhero text (Fingeroth 47-61). The secret identity, above all, promotes identification with the protagonist of the superhero text: for it is by way of the secret identity that "any accountant in any American city," Eco writes, can "feed the hope that one day, from the slough of his actual personality, there can spring forth a superman who is capable of redeeming years of mediocre existence" (108). But what is more interesting about this aspect of the genre is the burden that the dual identity criterion imposes on the superhero. The superhero's lot is to remain clandestine: to work underground, to act in secret. Indeed, according to Reynolds, what is established with the necessity of disguise (in order to conceal the secret self and safeguard the underlying or assumed identity) is more than a convention: in the genre it possesses the totemic quality of a taboo. The criterion of secrecy also fulfils another very important function that is structural to the genre: it puts the reader in the privileged position of sharing the secret - to the exclusion of the other characters in the narrative - with the hero. And it is the secrecy associated with dual identity and the reader's privileged inclusion in that secret world that are actually responsible for the identification patterns peculiar to the genre.

However, the alter-egos in Fear and Loathing cannot be considered "secret identities" in the conventional sense: it is common knowledge that Buck Caine is the Spirit; and Joe Gilmore is only really concerned with hiding his secret from his girlfriend Lynn (who is writing a "deconstructive" thesis about superheroes). And we can readily see why. At one point she says to Joe: "the idea of making it with a masked man revolts me!" He asks, rather sheepishly: "So what about the guy that hunts them down ... Marshal Law?"

"That fascist pig? That's even worse! That's really sick! 'Sides,
anyone who wears a costume like that's got to be gay! I prefer
someone normal like you!" (Mills and O'Neill 2002)

In another episode, when searching for Celeste on her wedding day, Marshal Law is attacked by a swarm of assorted costumed characters. During another ultraviolent, super-thrashing, they try to guess his real identity. They draw lots before pulling off his mask. And in a classically bathetic scene, exclaim ... "Who the frag are you?" before they try to pull off his face. And Marshal Law beats the hell out of all of them. 
In Fear and Loathing (issue two), the rape and murder of Lynn by the Sleepman is the primal traumatic event that loosens the bonds of civic responsibility in righteous anger for Marshal Law. It is this event that transforms the irrationality of his hatred of superheroes into a wrathful if virtuous cause for vengeance. At the same time, it knits his destiny into the structure of the superhero code. And noone seems to understand this fact more than the Sleepman himself:

He will hunt me down now. He will hunt us all down. He will not rest until he has found us. And given us ... what we oh, so richly deserve. (Mills and O’Neill 2002)

Therefore, manifestly, the death of Lynn is the critical episode that indicates adaptation to the superhero schema despite its subversion that we have considered characteristic of the double structure of Marshal Law. For in allowing Law to have a lover (and including sex-scenes) Mills and O'Neill exert severe pressure on the superhero code: for, as Eco indicates, like the mythical Messianic hero, the superhero must take an "implicit vow of chastity" (115) and this is to suggest that the hero cannot be tied down by any responsibilities that might make him vulnerable. As Bongco claims, if the superhero is allowed to have a lover, s/he is typically "marked by extreme vulnerability" (108); and this vulnerability actually signifies a generic weakness. Nothing can be allowed to stand in the way of the hero's mission; and the superhero genre, in clearing away the obstacles, transforms this clearing event into the source of that very mission. It is at the point in the narrative where Law discovers that Lynn has been killed that he is transubstantiated into an authentic hero in contradistinction to the variegated defectives multiplying in the city; he is now "alone to succeed or fail, to triumph or succumb" (Fingeroth 71). However, as events unfold, Law discovers to his horror and shame that it was the "heroic" vanity of his vendetta against the Public Spirit (and his efforts to pin the serial sex-crimes on the superhero) that led inadvertently to Lynn's murder. This discovery that he is complicit (however indirectly) in the murder of his own girlfriend is remarkably similar to the function of the death of Peter Parker's uncle in Spiderman. Again (as is the case supremely for Batman) the death of someone close to the hero, who relied on him for protection, leads, in Reynolds' words, to the "obsessive need to expunge his sense of guilt and failure" in the accumulation of subsequent pyrrhic victories so characteristic of the superhero (67). As claimed, the authentic (super)hero cannot sustain deep personal connections, he must become, through a primal trauma, spiritually nomadic; the implication is that Marshal Law will go on beating the hell out of "superheroes" until he avenges and (simultaneously) atones for the death of his lover Lynn.

\section{The Vestimentary Code: The Superhero Costume}

The hero's harmonious nude beauty was the visible expression of his uncorrupted moral and mental qualities.

- Anne Hollander, Sex and Suits

Perhaps the most fundamental and distinctive characteristic of the superhero is 
hereby identified: the costume. Costume operates in the genre, according to Reynolds, "as the crucial sign of superheroism" (26). When a given character appears in costume, this sets in motion a response that elicits a series of related anticipations. For instance, it is a "signal that [the character] is now operating in his superhero identity and may at any moment be involved in violent conflict with costumed villains" (Reynolds 26).

Constituting the "vestimentary code" of the superhero, costume must function on two distinct semantic levels. First, it is necessary that the costume be immediately recognisable and second, it must be distinctively associated with its wearer. Different characters are distinguished from each other (and, most crucially the hero from the villain), through the costume's ability to "make a formal statement about the hero's personality" (Bongco 106). In fact, Bongco observes that the costume must so distinctively belong to a particular superhero as to be recognised even in silhouette (105), and there are plenty of choice examples of this throughout Marshal Law. As well as providing immediate indexical indicators for the identification of particular superheroes, the costume must also enable the reader to acknowledge when characters are acting in their superheroic capacities. Therefore different

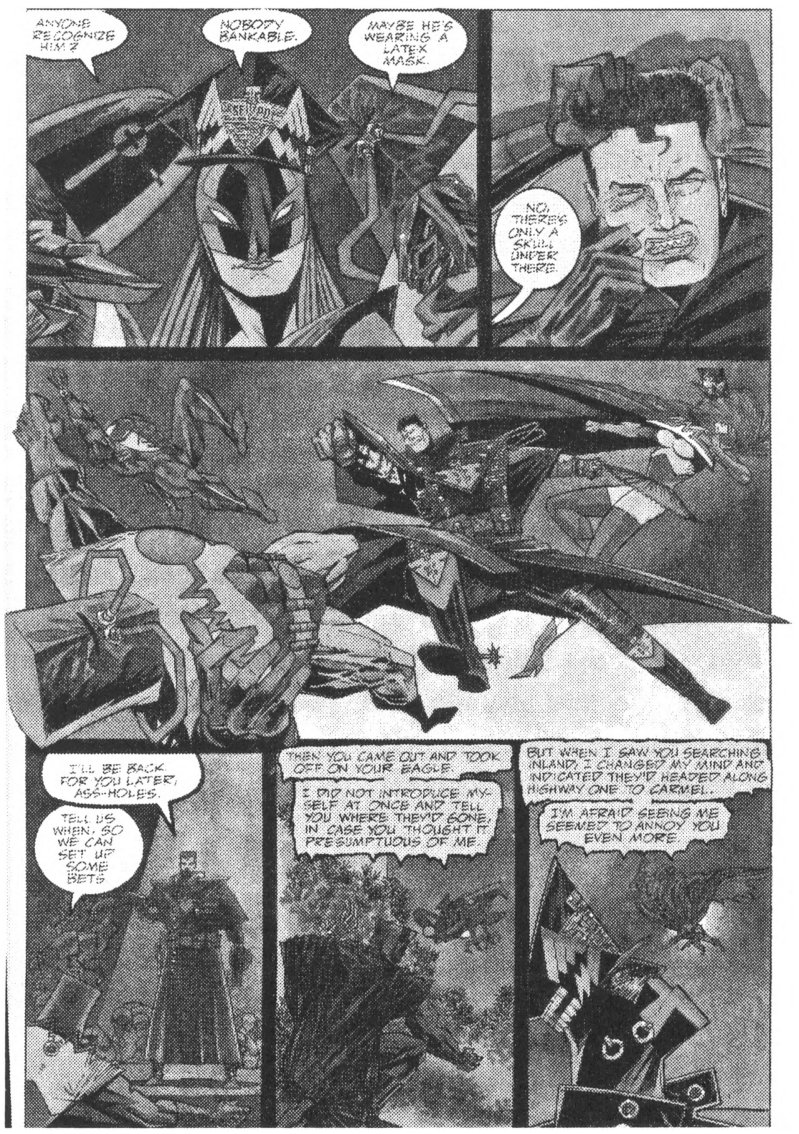
costumes are designed to exhibit something of the wearer's attributes, potencies or particular endowments. In this sense, the costume can be characterised as an objective correlative of the hero's (true) identity: "Thor's hammer, Wonder Woman's lasso, bracelets and tiara, Captain America's shield, Wolverine's steel claws, Silver Surfer's board, and so on" (Bongco 105).

Reynolds remarks that a specific costume represents - by selection from a paradigm of possible choices (helmet, mask, cape, leotard, breastplate, belt, 
shorts, tights, boots, etc.) - a specific statement in a generic system of structurally interrelated signs. Applied to a particular case this argument is less abstract. Batman's outfit according to the vestimentary code "is one utterance within the code that elegantly speaks the proper range of associations: night, fear, the supernatural." Once the paradigm-choices are combined, they begin to represent a syntagm richly connotative of Batman's mode of operation: "stealth, concealment, surprise" (26). Even in a deconstructive re-evaluation of the superhero genre like Watchmen, the costume code is followed and respected. We can make reference in this connection to Rorschach's confessional discovery of his characteristic layered latex mask in Watchmen. He describes in detail how he came upon the bizarre two-tone fabric that shifts and transforms in response to nervous stimuli. Producing patterns reminiscent of psychological projection splats, he fashions a mask from this material and Walter Kovacs becomes "Rorschach" (Moore 1986, VI, 10). In this sequence, Moore demonstrates a key function of the costume in the superhero genre. For, rather than being merely an index representing the power of the superhero, or even a parole instance of the costume-code, the costume is the power: it actually constitutes the potency of the superhero. To wear the costume is to become the character (Reynolds27). It is what makes the hero "super." In fact, Rorschach considers Kovacs (his un-costumed, "normal” self) to be his disguise; he even refers to his mask as his face: "I abandoned my disguise and became myself, free from fear or weakness or lust" (Moore 1986 V, 18).

Consisting of blue cape, skin-tight bodice in red and gold, blue overpants, red tights and slender boots, the costume worn by the Public Spirit is standard superhero fatigue. As already mentioned, it makes deliberate reference to the Public Spirit's patriotic prototypes, Superman and Captain America. The saturated primary colors are meant to generate a sense of bright optimism, innocence and morality. The response his costume elicits is the properly infantile fascination associated with the superhero's sublime-tremendous effect. On the other hand, Marshal Law wears a costume intended to elicit fear and absolute respect. It consists entirely of black leather with red (sometimes typographical) motifs and silver details. The mask is black with red stripes crossing nose and mouth; there are red zips at cheek and neck with silver ring pulls. The silver shield of the San Futuro Police Department (with its distinctive skull-motif) hangs around his neck and rests on a symmetrical red lightning design edged in white; two more red zips mark the seams from chest to abdomen where the words "Fear and Loathing" are marked out in red against the black leather. The belt is silver; its buckle an SFPD shield. The trousers are black leather with skull rivets down the outer seams. He wears (oddly highheeled) boots with spurs. A hat exaggeratedly peaked into O'Neill's favoured angular form with another SFPD shield tops off the ensemble.

Reynolds draws our attention to another aspect of the costume important for our analysis. In an episode of Watchmen, Nite Owl (Dan Dreiberg) and the Silk Spectre (Laurie Juszpeczyk) have sex - yet this is a consummation that can only take place while they are costumed (Reynolds 1992, 30-31). This scene, according to Reynolds, discloses an infrastructural "subtext" of the superhero code that has been in operation since the first episode of Superman - the fetishism (both religious and libidi- 
nous) of the costume. This suggests that the sublime-tremendous power associated with the superhero is sexual as well as physical and moral and the locus for this virile potency is the costume. The costume imparts to its wearer a mysterious aura of sexual potency: "women always prefer the character with the costume on rather than the alter-ego" (Bongco 107).

As we have already seen however, the case of Marshal Law is very different. Although his costume overtly advertises virile aggression, his lover, Lynn, is clearly repulsed by it. As for the Public Spirit's vestimentary potency, Mills and O'Neill subject this to extreme parodic inversion. Several scenes of Fear and Loathing depict middle-aged women at various public rallies transformed to drooling sex-crazed maenads in the presence of the Spirit. Indeed, in his introduction to the 2002 edition of Fear and Loathing, Mills comments that this aspect of the Public Spirit's appeal to the desperate housewife derives from the phenomenon of mature female hero-worship of cabaret entertainers like Barry Manilow or Tom Jones (consider the Chippendale-stripper syndrome associated with middle-aged women). "[Middle-aged women] fantasise about making it with their heroes, but they know it's never going to happen. The same mindset applies to the Public Spirit"' (Mills, in Mills and O'Neill 2002).

Certainly the most unique and perhaps disturbing element associated with Marshal Law's costume is the barbed wire twisted around his right arm. In fact, as is the case with Thor's hammer, Wolverine's steel claws and Silver Surfer's board, barbed wire becomes the iconological leitmotif associated metaphorically with the identity of Marshal Law. Prior to the wedding of the Public Spirit and Celeste, Marshal Law says: "I'll be there ... with a bouquet of barbed wire." And when he visits the cemetery at the very end of Fear and Loathing, he leaves a wreath of barbed wire at Lynn's gravesite.

An iconological interpretation of Marshal Law's costume will reveal that its central signification is pain. All its semiotic elements cluster around the concept of inflicting pain on the self as well as others. This is clearly the reason why O'Neill appropriated sado-masochistic bondage motifs when developing the iconography of the costume. (Reynolds has identified this association as already present in Batman whose mask recalls "the rubber or leather masks associated with rapists and serial sex killers" [!] [32].) This provenance is especially evident in the mask (arguably the transcendental signifier of the costume code ${ }^{8}$ ) but it is also present in the chains, zips, gloves and spurs that bristle on his costume. It also of course emphasises the fetishist and libidinous, polymorphously perverse aspects of the superhero genre (a continual concern of Mills and O'Neill's).

This analysis of the costume also provides an intertextual insight into the provenance of the character. British readers will perhaps readily discern the prototype of Judge Dredd beneath the surface of Marshal Law. The similarity of costume is obvious. For Dredd wears an almost identical black and red leather fatigue designed to inspire fear - similar chains connect the shield to the zip pull on his costume. But the similarities are deeper than this. For in Marshal Law we notice the same execution of summary justice, the same harder-than-hard, more-lethal-than-thecriminals attitude, the same concern for a transcendent form of justice, the same extreme lantern-jawed under-bite and the same kind of word-play in the name. Indeed, 
Mills is credited with the initial conception of the character and he wrote the first Dredd episode for 2000AD (McManus 9). There is also in the character of Marshal Law a very obvious debt owed to the appearance, attitude and style of Mad Max (1979).

As well as pain, the costume is styled according to the premise of fear. To the criminal it is necessary to appear completely ruthless, completely unscrupulous. This is no ordinary lawman. As the Persecutor exclaims in Marshal Law Takes Manhattan: "'You don't understand! He's worse than all you lot put together! He is really sick. He is utterly deranged. He is a total bastard'" (Mills and O'Neill 2003). And he has to look like a bastard too.

In the final pages of Fear and Loathing, through a series of intercalations from Lynn's thesis, a short disquisition on the costume code as it operates in Fear and Loathing is provided as a moment of meta-analysis in the text. Marshal Law's costume, she writes, seems deliberately designed in opposition to the Public Spirit's. For he "is the Public Spirit's Nemesis. The Sun Hero's Dark Twin. ... He is the Dark Star." His costume, Lynn continues, "advertis[es] his "hardness"" such that he "seems incapable of gentleness ... of love." Of course, as Lynn was unaware of Marshal Law's identity as Joe Gilmore, her lover, these quotations are deeply ironic. As she was murdered by the Sleepman, and Marshal Law is now shown visiting her grave, her words have added poignancy. He is shown with tears in his eyes. "And yet," she continues, "there are contradictions":

Is the barbed wire wrapped around his arm a sign of sado-masochistic practices? Or a subconscious desire to be punished for his past crimes? (Mills and O’Neill 2002)

With these rhetorical questions, Lynn reinforces the association with sado-masochism drawn above. However, her reference to unconscious penance in the second of these questions indicates another, perhaps surprising, feature of Marshal Law's costume. This is the theological trope of expiation through suffering that the costume's iconography inevitably alludes to. Indeed the barbed wire has Christological associations in its resemblance to the crown of thorns. And this is not accidental. The concept of the superhero, as suggested in our opening paragraphs above, carries unmistakable traces of the Messianic (McCue and Bloom 20). On one level, Marshal Law can be treated as an attempt to expose the subterranean popular-secular traces of the Messianic in the superhero concept. In fact the "Justice League of America" becomes in Fear and Loathing the Jesus League of America made up of such "heroes" as Stigmata (a superhero crucified on a jet), Shroud, Monstrance, Purgatory and, of course, the Public Spirit (who is shown in this episode with a crucifix instead of an eagle motif on his breast; and, as he levitates with arms outstretched, the moon behind his head becomes a white halo). Emphasising this connection, issue three was subtitled "Superhero Messiah" and its first page depicted a bomber-jet passing overhead with an image of the crucified Christ on its underside. As well as this there are multiple references to the religious scattered sporadically throughout the text. Mrs Mallon, who turns out to be Virago in disguise, is portrayed as extremely devout and intent on instilling a rigorous set 
of Christian values in her son Danny (who turns out to be the Sleepman). This also involves denying his superheroic capacities as repugnant and evil. However, her efforts only result in psychotic abreaction: in the attempt to gain his mother's approval, Danny becomes the Sleepman, the epitome of his mother's (and Marshal Law's) perceived conception of superheroes:

I am bacteria. I am the lowest form of life. I am a superhero. ... I wear a bag over my head because I'm ashamed of what I am and what I'm going to do. I am called the Sleepman. (Mills and O’Neill 2002)

However, the figure of Marshal Law strangely epitomises a central tenet of Christianity in opposition to the pseudo-Messianic superheroes: and this is a belief in the moral value of suffering. This is not only evident in his barbed wire and S\&M costume but also in a more profound way. In issue two, when Lynn is raped and murdered by the Sleepman, Marshal Law's hatred of the Public Spirit and obsession with bringing him to justice distorts his investigation and draws attention away from the real perpetrator. Had he been more objective and attentive to the available clues, he might have solved the case and realised the true identity of the Sleepman sooner, thereby saving Lynn's life. In the denouement of Fear and Loathing, when Marshal Law tracks down the Public Spirit to the deserted runway and they prepare to engage in final combat, the Spirit taunts Law. He informs him that for Danny (the Sleepman) Marshal Law was a role model, a kind of super-ego ideal with which he could identify and become, through transference, the proper object of Marshal Law's wrath:

\begin{abstract}
But he knew you could never return his love because you hated superheroes. The only way he could resolve this conflict was by becoming the Sleepman ... a reflection of your view of superheroes. (Mills and O'Neill 2002)
\end{abstract}

Thus faced with the knowledge of his indirect complicity in Lynn's death, Marshal Law is horribly reminded of the squalid reality behind the myth. The cycle continues: just as Joe Gilmore in his youth treated the Public Spirit as a role-model, Danny had seen Marshal Law in the same light. All that the cycle leaves behind is a trail of damaged subjectivity.

\title{
TheTransvestimentary Code: Marshal Law and the Carnivalesque
}

... superheroes don't wear costumes in order to fight crime, they fight crime in order to wear the costumes

- Scott Bukatman, Matters of Gravity

It seems questionable that texts promoting a theoretical analysis of the superhero (Reynolds' Superheroes: A Modern Mythology, Bongco's Reading Comics and Klock's How to Read Superhero Comics and Why) - and that include detailed assessment of critical revisions of the genre like Moore's Watchmen and Miller's Dark Knight Returns - make no reference to Marshal Law. Why is this? Perhaps 
Mills and O'Neill's text is just too derogatory to be included as a proper contribution to the superhero genre even as an instance of critical deconstruction. But what can a "proper contribution" mean in this context? As we have demonstrated above, Marshal Law not only provides its own meta-critical commentary (often by way of O'Neill's imagery) as a structural component of the text but also represents an incidence of parole in the langue of the superhero code. This enables the creators to comment critically on the genre from within the alibi of the storyline (arguably neither Miller's nor Moore's texts are able to achieve this without dissolving the "reality effect" their narratives depend on).

Early in the analysis we claimed that the "polyvalent" presentation of Marshal Law can be theoretically elucidated with reference to the category of the carnivalesque. We are now in a more secure position to develop that claim. We will also argue that the particular kind of critique of the superhero genre undertaken by Mills and O'Neill in Marshal Law can be thematised with reference to this category. In Desire in Language, Julia Kristeva develops Bakhtin's theory of carnival into the semiotic category of the 'carnivalesque.' Above all, the scene of the carnival, Kristeva writes, "challenges God, authority, and social law ... it is rebellious." The carnival represents a deeply desired need to challenge socio-symbolic conventions through the practice of irreverence. Such a desire for irreverence, according to Kristeva, expresses itself in disrespectful and subversive forms of social discourse (78). In Fear and Loathing, the presence of distinctively carnivalesque treatment is most obviously apparent in the puns, double (and single) entendres and the myriad portamanteau-constructions that permeate O'Neill's imagery (and often generate the hilarious-absurd effect associated with the carnivalesque). For, according to the regime of the carnivalesque, language is exploited in its

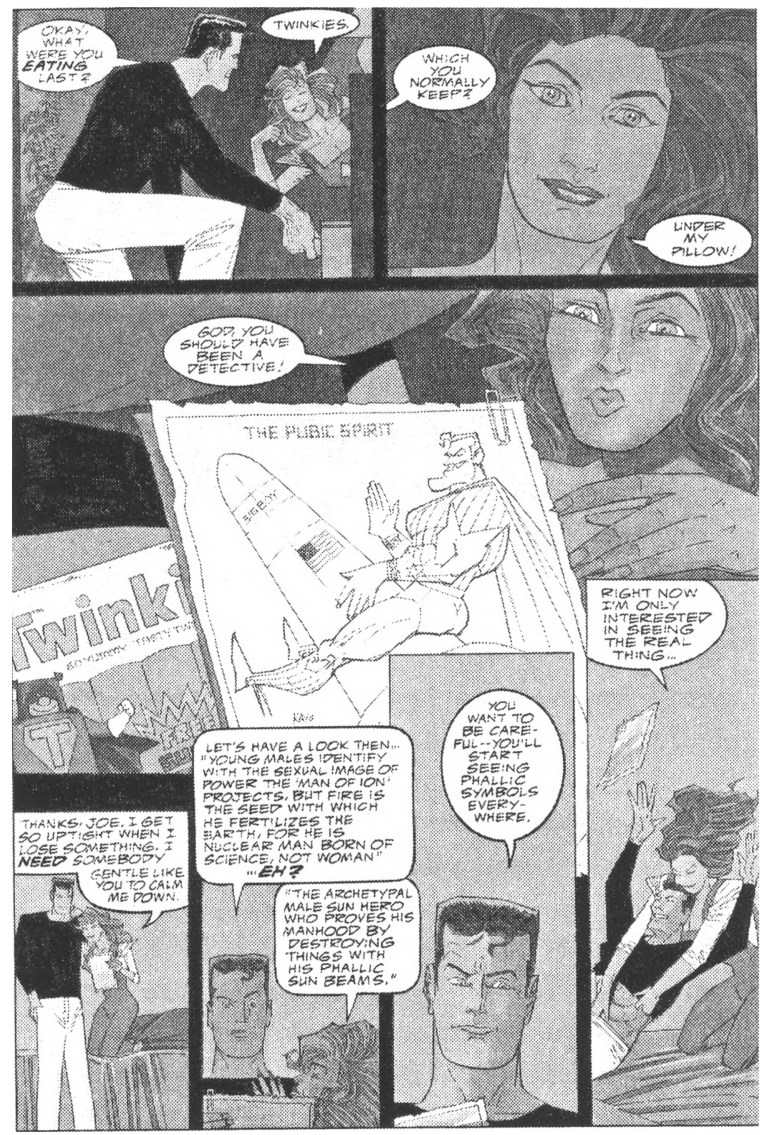


richness and intransigence; it is manipulated on a material, physical level: as a result, Kristeva notices, "it provokes laughter" (79). For the particular type of comedy associated with the carnivalesque involves verbal inversion and corruption: the scatological vernacular and porn-ergot of Marshal Law are prime instances of this discursive carnivalesque corruption.

John Fiske (1989), in contrast to Kristeva, emphasises other aspects associated with Bakhtin's theory of the carnival: namely, the spectacular and grotesque. In the carnival state, in opposition to the morality of social discipline, repressed subordinated pleasure-forms are given expression through the spectacle of physical excess. Carnival assumes its distinctive forms through "laughter, excessiveness (particularly of body and bodily functions), by bad taste and offensiveness, and by degradation" (82). Again this aspect of the carnivalesque is evident in the richly colored, boisterous and bawdy Hogarthian scenes, crammed with background incident and supplementary action, so characteristic of O'Neill's artwork (especially in Fear and Loathing). So often, as in the carnivalesque, the site of liberated transgression (not only in Marshal Law but in the superhero text in general) is the human body: its "emphasis on excessive materiality foregrounds the body" (Fiske 84). In Marshal Law, Mills and O'Neill's investigative exposure of the superhero genre frequently takes place with reference to the excessive body; but, as Bukatman highlights in exhaustive detail in Matters of Gravity, the superhero text has always been an utterly somatic discourse, a discourse where the "body is obsessively centred upon" (49). The physique of the superhero is an infinitely expandable substance subject to elastic exaggeration and "hypermuscular" inflation (55).

In Marshal Law, this aspect of the superhero body is focused on for satirical intent. By turns bloated and flatulent - or thickset and varicose - the body is inflated (but not much more than in regular superhero comics - and that's the point) to the point where it becomes openly grotesque so that it exists only in its excessive signs. This is most evident in the final episode of Fear and Loathing when the Public Spirit gets "hard" - "While he was 'hard,' he was capable of concentrating his electromagnetic field to repel bullets ... or lift huge metallic objects" (Mills \& O'Neill 2002). The grotesque body signifies a morbid contrast to the athlete's body, which is displayed for its formal perfection and classical beauty. In contrast, the grotesque body is displayed precisely as an obscene somatic spectacle. While hard, the Public Spirit is truly rendered grotesque: O'Neill has penned an obscene quasi-human figure, unspeakably pumped-up and pneumatic. Veins stick out prominently on his neck and arms. In direct contradistinction to his Platonic name, the Public Spirit has become nothing but a body in a state of excessive corporeality. In the context of the superhero however, Mills and O'Neill have added a new dimension to the excessive body: phallic excess. While hard, the Public Spirit becomes distended, tumescent, swollen - erect. 'As he 'pumped ions,' he grew in stature, swelling up so his veins stood out in knots on his body ... and electrical energy spurted out. The big question was ... how long could he keep it up?" (Mills \& O'Neill 2000). As any comics-reader will be aware, the provenance of this phallic body can be attributed to the Incredible Hulk.

For the most part, comics are "conceived with an adolescent audience in mind" 
(Reynolds 81). This audience is also gendered male, resulting in an "excription of women" structural to the superhero code (Bongco 108). In other words, the audience for an instance of the superhero code is assumed to be, and therefore identified as male: those interpellated by the genre, specifically, are adolescent males. Identified by the text, these males are thereby encouraged to identify with its thematic content, its iconographical motifs and narrative structure. Thus comic-book characters in general (and superheroes in particular) hold a particular fascination for boys. Why is this? It is the same reason why adolescent boys are fascinated with wrestling and body-building: the grotesque body provides an imaginative link between their immature yet growing and changing physique and the finished adult body. That is to say, the grotesque body as displayed in the superhero, the wrestler and the body-builder seems to provide an immediate and satisfactory reification of the desire to grow, to "be big and powerful." However, and this is perhaps a more psychologically sophisticated explanation, the grotesque body also provides a more or less precise analogue of the adolescent body as experienced by one subject to its transformations. The changes associated with puberty appear gross and unmanageable - amplified to the point of obscenity - from the perspective of the adolescent. And thus a tendency to identify with characters whose bodies are subject to uncontrollable change (the Incredible Hulk) or are undergoing gradual but powerful immanent alteration (Spider-Man) develops in adolescence. For Bukatman, "[t]hese comics presented as obvious an allegory of pubescent metamorphosis as one could imagine-The Hulk, for example, got big and hairy and his voice changed." Bukatman adds: "Go figure" (54).

One of the primary functions of the superhero costume, according to Bukatman, is to emphasise the "(increasingly exaggerated)" muscular body of the superhero beneath: thus "superhuman bodies have al-
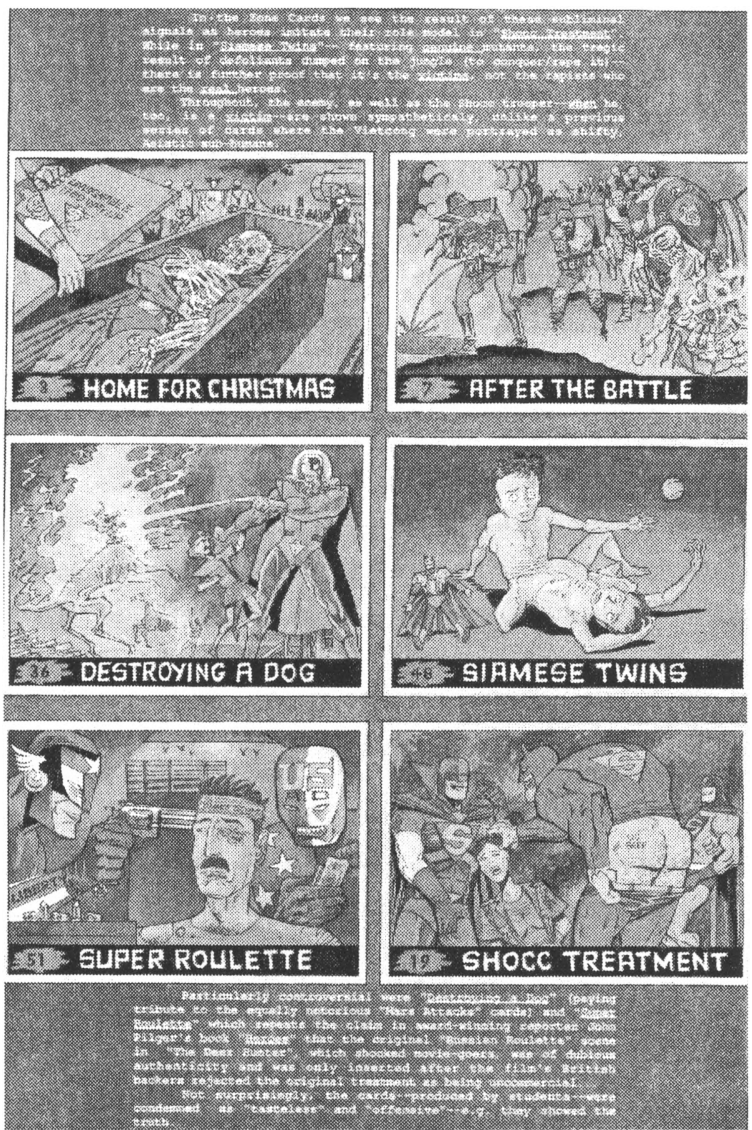
ways been naked bodies exhibited to a very public gaze" (215). The vestimentary code of the superhero (discussed at length above) reinforces the homoerotic structure of this "gaze" (indeed, even Barthes draws attention to the feminised look and campy gestures of wrestlers): tights, bulging pectorals under skin-tight bodices, (over)underpants, tiny feminine feet and flourishing cape, are the elements that constitute the generic costume of the superhero; together they make up an instance of high-camp hybridisation. Reynolds likewise recognises that the superhero exhibits an "exaggerated and kinky form of macho sex appeal, which puts them, in the fetish stakes, on a par with many of the superheroines" (81). And there is widespread agreement among comic-book theorists that the costume, the principal characteristic of the superhero genre, is the vehicle of this appeal. Thus, we conclude, the vestimentary code of the superhero is, properly considered, a transvestimentary code. For the trans-vestite typically assumes an alternative identity through constructing a garment syntagm chosen from a radically different paradigm set (a set usually associated with the opposite gender). This assumption of different identities is also a key component associated with the carnivalesque scene. Therefore, pace Lynn's thesis, the macho aspect of the superhero is deeply ambivalent.

Mills and O'Neill's Marshal Law subjects all the salient characteristics of the superhero genre, but the body and the vestimentary codes in particular, to subversive inversion. However, in Fear and Loathing, these codes are precisely replicated, and yet in their replication, made overt and explicit. The "offensive" aspects of the generic comic-book superhero are thus emphasised (ironically) for comic effect. So, we conclude, Mills and O'Neill appropriate the code of the superhero genre in order to more effectively undermine it according to its own rigorous rules and regulations.

Now, finally, we can thematise Marshal Law theoretically. Kristeva argues that the subversive structure (and cynical ethos) associated with the carnivalesque follows a semiotic law: that of ambivalence. For the "scene" of the carnivalesque, she writes, "is the only place where prohibitions [conventions, rules, regulations] ... and their transgression ... coexist" (Kristeva 1981, 79). What Mills and O'Neill discovered with Marshal Law, despite what may appear prima facie (and despite their express initial intentions) is that in order to subvert and transgress the conventions of the superhero genre, it is also necessary, paradoxically, to ultimately respect them by observing them. So - and this may explain why its intervention did not prevent the superhero industry from continuing to reproduce variants of its "innocent" avatars - although employed in a radically and grotesquely exaggerated mode, the conventions of the superhero remain unaffected by the interrogation they are subjected to in Marshal Law even within the comic itself because they are (they have to be) ultimately respected and validated even in (or, rather, because of) their transgression. For, in the carnivalesque, as Kristeva explains, destructive and seditious impulses are experienced as a thoroughly enjoyable emancipation from symbolic orthodoxy only because they ultimately respect and in fact often reinforce the very orthodoxy they transgress. It is the ambivalent status of the carnivalesque that enables transgression to appear in an environment (like Marshal Law) that simultaneously demands obedience to the conventions. So, although Mills and O'Neill did not set out to rehabilitate a worn out genre and, in fact, appeared more 
intent on precipitating the termination of what was to them an exhausted framework, they, despite their intentions, ended up fortifying the genre at a higher level.

Discussing the work of Walter Benjamin, George Steiner once referred to him as a "parodist theologian" (19). How does he define this concept? "There is scarcely a node," he says, "in Benjamin that is not akin to or derived from, the theological" (19). Yet his work also represents, vitally, a materialist critique of theological thinking. For he worked, according to Steiner, inside and outside religion, simultaneously "within and against the grain of theology ... in a crucially transvestite mode as did Karl Marx" (19; emphasis added). We would like to suggest that, as Mills and O'Neill's carnivalesque inversion of the superhero genre, in a similar vein to Benjamin's, operates both inside and outside the code, in "the only place where prohibitions ... and their transgression ... coexist," within and against the grain, they are following the transvestite logic we have associated with the carnivalesque.

\section{Notes}

${ }^{1}$ See Superman 74-75, 1992; see also commentary in Reynolds (1992, 122-124) and Bongco (2000, 115-116).

² See Gary Engle (1987), “What Makes Superman So Darned American?” Engle argues that Superman - the paradigmatic superhero - is also a uniquely American concept, an identification that is an essential aspect of Mills and O'Neill's critique. This identification is reinforced by Reynolds (1992) and Fingeroth (2004).

${ }^{3}$ It has since been republished in graphic novel format by Titan Books, London: 2002 (the edition I will refer to throughout).

${ }^{4}$ In fact they were part of the original creative team; O'Neill was art editor for the comic and Mills was involved in the creation of the comic's most successful, popular and venerable character, Judge Dredd. They also worked together on Metalzoic for DC (subsequently republished in 2000AD, 1986).

5 "Once Superman took to the air in earnest, all the familiar characteristics were in place" according to McCue and Bloom (21); see also Reynolds' analysis of Siegel and Schuster's Superman (12); and Eco (122): "Superman is the most popular of the superheroes we talk about: he not only represents the forerunner of the group (in 1938), but of all the characters he is still the one who is most carefully sketched, endowed with a recognisable personality, dug out of longstanding anecdote, and so he can be seen as the representative of all his similars."

${ }^{6}$ See Kearney (74).

${ }^{7}$ Of course, in this case, the loss of any loved one is identified with the "loss of parents" criterion; Fingeroth's orphan condition is replicated in any loss (for instance the loss of Max's family in Mad Max is a classic example) that leaves the hero alone and with nothing left to lose (and therefore very, very dangerous).

${ }^{8}$ As Bukatman points out, "The mask is the perfect synecdoche for the superhero, the mysterious totem that makes everything possible" (212). 


\section{Works Cited}

Bakhtin, Mikhail. Rabelais and his World. Trans. Helene Iswolsky. Cambridge: The MIT Press, 1965.

Barthes, Roland. The Fashion System. Trans. Matthew Ward and Richard Howard. New York: Hill and Wang, 1983.

---. Image, Music, Text. Trans. Stephen Heath. London: Fontana Press, 1977.

---. "Textual Analysis: Poe's 'Valdemar."' Modern Criticism and Theory. Ed. David Lodge. London and New York: Longman, 1988. 172-195.

Bongco, Mila. Reading Comics: Language, Culture, and the Concept of the Superhero in Comic Books. New York and London: Garland Publishing Inc.

Bonner, Michael. Simon Bisley and Pat Mills Interview. Deadline 8. (1989): 1922.

Bukatman, Scott. Matters of Gravity: Special Effects and Supermen in the $20^{\text {th }}$ Century. Durham: Duke UP, 2003.

Carrier, David. The Aesthetics of Comics. Pennsylvania: State University Press, 1999.

Cobley, Paul. Narrative. London: Routledge, 2001.

Critchley, Simon. The Ethics of Deconstruction. Oxford: Blackwell, 1993.

Culler, Jonathan. Barthes: A Very Short Introduction. Oxford: University Press, 2002.

Derrida, Jacques. Dissemination. Chicago: Athlone Press, 1981.

Eco, Umberto. "The Myth of Superman." The Role of the Reader: Explorations in the Semiotics of Texts. Bloomington: Indiana UP, 1979.

Engle, Gary. "What Makes Superman So Darned American?" Superman at Fifty: The Persistence of a Legend! Ed. Dennis Dooley and Gary Engle. Cleveland OH: Octavia Press, 1987. 79-87.

Fingeroth, Danny. Superman on the Couch: What Superheroes Really Tell Us about Ourselves and Our Society. New York: Continuum, 2004.

Fiske, John. Television Culture. London : Routledge, 1987.

---. Understanding Popular Culture. London: Routledge, 1989.

---. Introduction to Communication Studies. London: Routledge, 1990.

Freud, Sigmund. "The Ego and the Id" (1923). The Freud Reader. Ed. Peter Gay. London: Vintage, 1989.628-660.

Kearney, Richard. On Stories. London: Routledge, 2002.

Klock, Geoff. How to Read Superhero Comics and Why. New York: Continuum, 2002.

Kress, Gunther and Theo van Leuuwen. Reading Images: the Grammar of Visual Design. London: Routledge, 1996.

Kristeva, Julia. Desire in Language: A Semiotic Approach to Literature and Art. Trans. Thomas Gora, Alice Jardine and Leon S. Roudiez. Ed. Leon S. Roudiez. Oxford: Basil Blackwell, 1981.

McCue, Greg S., and Clive Bloom. Dark Knights: The New Comics in Context. London: Pluto Press, 1993.

McManus, Steve. “The Story of Dredd." Judge Dredd Annual. London: 
Fleetway, 1981, 8-10.

Mills, Pat and Kevin O'Neill. Marshal Law: Fear and Loathing. London: Titan Books, 2002.

---. Marshal Law: Fear Asylum. London: Titan Books, 2003.

Morrison, Grant and Dave McKean. Arkham Asylum: A Serious House on Serious Earth. New York: DC Comics, 1989.

Reynolds, Richard. Super Heroes: A Modern Mythology. Jackson: UPof Mississippi, 1992.

Roebuck, Lester. "The Good the Bad and the Oedipal" Superman at Fifty: The Persistence of a Legend! Ed. Dennis Dooley and Gary Engle. Cleveland OH: Octavia Press, 1987.

Ross, Jonathan. "The Next Big Thing (Batman: the Killing Joke)." Escape 13 (1988): 29.

Schmitt, Ronald. "Deconstructive Comics." Journal of Popular Culture 17.1 (1992): 153-161.

Seigel, Jerome and Joe Schuster. "Superman." Action Comics 1. New York: DC Comics, 1938.

Steiner, George. "To Speak of Walter Benjamin." Benjamin Studies/Studien: Perception and Experience in Modernity. Amsterdam: Rodopi, 2002. 11-24.

Trushell, John M. “American Dreams of Mutants: The X-Men - 'Pulp' Fiction, Science Fiction, and Superheroes." Journal of Popular Culture 38. 1, (2004): 149-168. 